accepts Wood's thecry that the Paramyidae are the ancestral rodents from which (perhaps in a form near the Upper Eocene Uriscus) arose the seiurids. The author considers the Prosciurinae unlikely sciurid ancestors. The bulk of the paper is devoted to the systematic account of all known North American spocimens: the discussion parts are largely devoted to details of comparative anatomy and its taxonomic significance. Most of the material is dental; a few skulls aro known; neithor braincaso nor narial region is described though two are figured. Few post-cranial remains are known, but the author lists the expected skeletal characters. Black summarizes the floral and climatic changes in western North America in Tertiary times and relates the adaptive radiation of sciurids to this. The change from contracting forests to grasslands, begun in late Oligocono, is paralleled by the appearance in early Miocene of ground squirrels, probably descended from chipmunk-like types of late Oligocene. The work is well illustrated with plates which appear to be based cn photographs of pencil drawings. If the Old World sciurids could now be as well revised, we would be in possession of an excellent picture of this interesting family.

\section{Lederle Medical Student Research Fellowships}

Thr Lederle Laboratories Division of the American Cyanamid Company is making available medical student research fellowships to medical schools throughout the United States and Canada for the year 1964. These fellowships, in amounts not exceeding 650 dollars per annum for any one individual, are intended to relieve in part the finaneial burden of students who desire to devote their summer vacation to research in preclinical departments. Students who apply for these research fellowships must be of good scholastic standing and must have the consent cf the faculty member under whose supervision their research is to be conducted. The selection of students to receive such awards will be made by the Dean of the modical school, or by the regularly constituted committee of the faculty charged with such selections. By special permission of the Dean or the Fellowship Committoe of the school, the student may carry on such research in another medical school provided that satisfactory arrangements are previously made with the faculty member of the school and the department in which the student is to carry on his research.

\section{Harkness Fellowships of the Commonwealth Fund}

The following appointments to Harkness fellowships of the Commonwealth Fund have been announced: P. W. Atkins (Leicester), physical chemistry; N. L. Browse (Westminster Hospital), surgery; D. E. Eccles (Ministry of Public Buildings and Works), civil engineering; C. V. F. Henfrey (Oxford), anthropology; L. L. Iverson (Cambridge), biochemistry; Miss M. M. Knight (Middlesex Hospital), social studies; G. R. G. Lowison (Cambridge), hydrodynamics; B. Moores (Manchester College of Science and Technology), industrial engineering; Miss L. S. Pearson (Leeds), genetics; A. G. Robiette (Cambridge), spectroscopy; R. D. Rowe (Oxford), mechanical engineering; P. A. Strittmatter (Cambridge), astrophysics; D. L. Weaire (Cambridge), thooretical physics.

\section{The Night Sky in May}

NEw moon occurs on May 11d $21 \mathrm{~h} 02 \mathrm{~m}$ U.T. and full moon on May $26 \mathrm{~d} 09 \mathrm{~h} 29 \mathrm{~m}$. Tho following conjunctions with the Moon occur: May $6 \mathrm{~d} 08 \mathrm{~h}$, Saturn $3^{\circ}$ N.; May $14 \mathrm{~d} 16 \mathrm{~h}$, Venus $4^{\circ} \mathrm{N}$. Mercury is in conjunction with Mars on May 10d 13h, Mercury being $1.9^{\circ}$ S., Mars with Jupiter on May $19 \mathrm{~d} 19 \mathrm{~h}$, Mars being $0.6^{\circ} \mathrm{N}$., and Mercury with Jupiter on May 25d 14h, Mercury being $3^{\circ} \mathrm{s}$. Morcury is too close to the Sun for observation. Venus is an evoning star, setting at $23 \mathrm{~h} 50 \mathrm{~m}, 23 \mathrm{~h} 30 \mathrm{~m}$ and $22 \mathrm{~h}$ $20 \mathrm{~m}$ on May 1,15 and 31 , raspectively. Its stellar magnitude is $-4 \cdot 2$; greatest brilliancy is attained on May 13 .
Its distance decreases during the month from 51 to 32 million miles, and the visible portion of the apparent disk from 0.378 to $0 \cdot 108$. Mars and Jupiter aro too close to the Sun for observation. Saturn rises about $2 \mathrm{~h}$ before tho Sun, but conditions are not yot favourable for observation. Thero is one occultation of a star brighter than magnitude 6 visible at Groonwich: May 22d $21 \mathrm{~h}$ $15 \cdot 1 \mathrm{~m}, 80 \mathrm{Vir}$. (disappearance). The $\eta$ Aquarid meteors are active during May 1--8, but they are not well observed from latitudes so far north as Britain.

\section{Announcements}

Prof. A. Holmes, emeritus profossor of geology and mineralogy in the University of Edinburgh, and Prof. P. Eskola, emeritus professor of geology and mineralogy in tho University of Helsinki, have been awarded jointly the Vetlesen Prize of Columbia University, New York, for outstanding achievement in science relating to " $\mathrm{a}$ clearer undorstanding of the Earth, its history or its rolation to the universe". The Vetlesen Prize, which was first awarded in 1960, consists of a gold medal and 12,500 dollars.

Dr. N. A. DE Bruyne, chairman and managing director of Techne (Cambridge), Ltd., has received tho Adhesives Award of the American Society for Tosting and Materials in recognition of his outstanding work in the science of adhesion and the technology of adhesives.

THE sixteenth intornational symposium on "Crop Protection" will be held in Ghent on May 5. Further information can be obtained from Prof. J. van den Brande, Rijkslandbouwhogeschool, Coupure Links 235, Ghent.

THE annual symposium of the medical staff of the Memorial Hospital of Long Beach, California, will be held at the Hospital on May 20. Further information can be obtained from Dr. G. X. Trimble, Memorial Hospital of Long Beach, 2801 Atlantic Avenue, Long Beach, California.

THe annual general meeting of the Iron and Steel Institute will be held at the Institution of Civil Engineers, London, during May 6-7. The meeting will include sessions on: process selection; the role of national steel specifications; hot-blast stoves. Further information can be obtained from the Secretary, Iron and Steel Institute. 4 Grosvenor Gardens, London, S.W.1.

A symposium, organized by the British Society for Research on Ageing, will be held at the Ciba Foundation, London, on May 13. Topics under discussion will include: the ageing of connective tissue; lipid metabolism in ageing; metabolism of leucocytes; ageing and cysteine metabolism; ageing changes in invertebrates. Further. information and tickets can be obtainod from Dr. D. A. Hall, Department of Medicine, The General Infirmary, Loods 1 .

A CONFERENCE on "The Laser", sponsored by the New York Academy of Sciences, will be held in Now York during May 4-5. The programme will include sessions on: tho physics of lasers; developments; applications to science, industry and the military; applications to biology and modicine; tho offoct of the laser on the eye. Further information can be obtained from the Executive Director, New York Academy of Sciences, 2 East Sixty-third Stroot, New York 21, N.Y.

Erratum. Logos Press, Ltd., has written to the Editor stating that it wishes to retract a statement made in its advertisement on p. cex of the November 2, 1963, issue of Nature to the effect that it would be publishing a monograph by Dr. I. R. Beattio on The Infra-red Spectra of Inorganic Compounds. The statement was made in error, and Logos Press, Ltd., offors its apologies to the outhor for any inconvenience that it may have caused. 